\title{
Dispersal and spatiotemporal distribution of Protapion fulvipes in white clover fields: implications for pest management
}

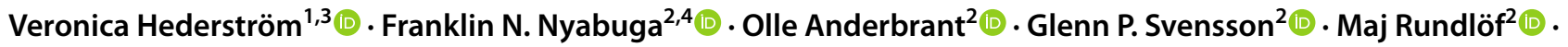 \\ Åsa Lankinen ${ }^{1}(1) \cdot$ Mattias C. Larsson ${ }^{1}[0$
}

Received: 11 January 2021 / Revised: 21 June 2021 / Accepted: 6 July 2021 / Published online: 16 July 2021

(c) The Author(s) 2021

\begin{abstract}
Yield loss caused by insect pests remains a substantial problem in agriculture. Chemical control, with potential negative effects on non-target organisms, is still the main tool for pest management. For pest species with limited dispersal capacity, rotation of the crop in time and space has potential as an alternative management measure. This is particularly important in organic farming, where most agrochemicals are prohibited, but also relevant as a complementary pest management strategy in conventional agriculture. Clover is an important crop used for animal feed and as green manure; however, seed-eating weevils can severely limit the seed yield. We hypothesized that the previous year's clover seed fields constitute the major sources of weevil pests. Consequently, a greater distance to, and a smaller pest load from, this source should reduce the number of weevils colonizing the new seed fields. To map population dynamics and dispersal range of Protapion fulvipes, an economically important seed weevil specialized on white clover, we conducted field studies over four years in 45 white clover seed fields. We found that $P$. fulvipes overwinters close to its source field and disperses to new fields in early spring the following year. Pest abundance increased with pest load in the previous year's seed field, but decreased by $68 \%$ per $\mathrm{km}$ distance to the previous year's field. Thus, separation of seed production fields between years by $2-3 \mathrm{~km}$ would create a spatiotemporal pest management tool to reduce the pest infestation below the estimated economic injury level.
\end{abstract}

Keywords Trifolium repens $\cdot$ White clover seed weevil $\cdot$ Agricultural pest $\cdot$ Dispersal distance $\cdot$ Clover seed production

\section{Key Message}

- The seed pest Protapion fulvipes severely limits white clover seed yields

- We mapped dispersal and spatiotemporal distribution of the pest over 4 years in 45 seed fields

Communicated by Vesna Gagic.

Veronica Hederström

veronica.hederstrom@cec.lu.se

1 Department of Plant Protection Biology, Swedish University of Agricultural Sciences, Alnarp, Sweden

2 Department of Biology, Lund University, Lund, Sweden

3 Present Address: Centre for Environmental and Climate Science, Lund University, Lund, Sweden

4 Present Address: Department of Biological Sciences, University of Embu, Embu, Kenya
- Weevil population and field size one year influence the weevil population the following year

- Pest abundance decreases, and seed set increases, with distance to the previous year's field

- Moving the seed field 2-3 km between years would allow spatial escape from the weevil pest

\section{Introduction}

Despite extensive use of chemical control, crop yield losses caused by pests have remained proportionally constant or even increased in some areas in the latter half of the last century (Oerke et al. 1994; Pimentel et al. 1991; Oerke 2006). Although integrated pest management today could offer a wide diversity of measures (Kogan 1998; Zalucki et al. 2009), the reality is that pest control still depends mainly on insecticides (Dent 2000; Rebek et al. 2012). To design appropriate integrated pest management (IPM) measures that can reduce the pest load below the estimated economic 
injury level, where insecticides are redundant, knowledge about pest biology is crucial.

Growing the same crop in the same field for several years in a row is known to cause accumulation of crop diseases, pests and depletion of nutrients (Bullock 1992; Mohler and Johnson 2009). For pest species with limited dispersal capacity, moving the resource in time and space by crop rotation can be an important measure to control population buildup (Bullock 1992; Dent 2000; Mohler and Johnson 2009). This measure, however, requires knowledge on pest dispersal ability. We know that insects disperse and migrate to escape unfavorable environmental conditions or in search of resources such as suitable habitat, food, mates and oviposition sites (Wolfenbarger 1946; Dingle and Drake 2007; Dingle 2014; Chapman et al. 2015). Their dispersal distances differ, ranging from very short distances (Wolfenbarger 1946) to several hundreds of kilometers (Kim and Sappington 2013). Nevertheless, for many insect species, dispersal distances are unknown.

The white clover seed weevil Protapion fulvipes, Geoffroy, 1785 (Coleoptera: Apionidae) is an economically important pest, which substantially reduces seed yields of white clover, Trifolium repens L (Gønget 1997; Langer and Rohde 2005; Hansen and Boelt 2008); an important forage legume for grazing livestock in many temperate areas (Baker and Williams 1987). As clover efficiently fix atmospheric nitrogen, it is an essential crop in the organic farming sector, where inorganic fertilizers are prohibited (Stockdale et al. 2001). However, predation by seed-eating weevils is limiting yields particularly in organic clover seed production (Langer and Rohde 2005; Lundin et al. 2017).

Overwintering adult $P$. fulvipes emerge in early spring, around mid-April, after which they locate host plants, $T$. repens and T. hybridum L. (Markkula and Myllymaki 1957, 1964; Gønget 1997), to feed on until sexually mature (Freeman 1967). After mating, females oviposit inside clover inflorescences (Freeman 1967; Gønget 1997). Hatched larvae feed on ovules and developing seeds (Jones 1950; Freeman 1967), pupate, and in late summer, often coinciding with clover seed harvest, adults emerge from inflorescences and feed from clover leaves before dispersing to overwintering areas (litter or tall grass, Ohlsson 1968; Freeman 1967). At northern latitudes, P. fulvipes has only one generation per year (Jones 1950; Freeman 1967). The substantial variation in weevil abundance among fields and years (Freeman 1967; Nyabuga et al. 2015) may be caused by varying survival rates following winter conditions (Freeman 1965) as well as by proximity to previous year's clover fields (Langer and Rohde 2005). Protapion spp. weevils have been reported to easily move up to $500 \mathrm{~m}$ (Ohlsson 1968; Kruess and Tscharntke 1994), and the suggested pest control method of growing white clover on fields away from any insect sources, e.g., previous year's clover field (Bovien and
Jørgensen 1934, 1936), would work only if fields are separated by long enough distances. Langer and Rohde (2005) reported that presence of an immediate pest source within $1 \mathrm{~km}$ was linked to a higher number of weevils, indicating the potential for spatial escape in IPM, but did not provide any detail about the general relationship between inter-field distance and pest pressure. In Sweden, growers are advised to wait five years before growing white clover in the same field again, and recently an advice of a distance of at least $500 \mathrm{~m}$ between fields in subsequent years has been added (Swedish Board of Agriculture, 2019). Comparatively, Lundin et al. (2016) showed that abundance of Protapion trifolii (L.), attacking red clover Trifolium pratense L., tended to increase when a red clover field was within $800 \mathrm{~m}$ from a previous year's field. However, $P$. trifolii, in contrast to $P$. fulvipes, flies minimally and primarily walks during dispersal (Bovien and Jørgensen 1936), indicating that $P$. fulvipes might have a greater dispersal range than $P$. trifolii. Hence, research on the potential to use spatial escape as a pest control measure in white clover, and an accurate distance recommendation, is still needed.

Our aim was to investigate the potential to reduce pest pressure and yield loss in white clover seed production using spatial planning. We did this by studying spatiotemporal dynamics of $P$. fulvipes and its influence on seed set over four years in 45 white clover seed fields in southern Sweden. In Sweden, seeds are sown into a cereal crop the year before the seed harvest year (Svensk raps 2018) (Fig. 1). It is, however, unclear whether the weevils locate clover seedlings present in the new seed field already in the autumn or in the following spring. We hypothesized that the previous year's clover seed field constituted the major pest source for new seed fields in the agricultural landscape and that a longer distance to this source would significantly reduce the number of weevils colonizing the new seed field. We also predicted a positive relationship between source field size, its abundance of seed weevils and the potential number of seed weevils dispersing from the source field (i.e., pest load). Our study addressed the following specific questions: (1) Do clover seed weevils overwinter by the recently harvested seed field or by the newly sown seed field? (2) Does the pest load from previous year's seed field influence subsequent attacks and seed loss in the new, adjacent seed field? (3) Can an increased distance between subsequent fields mitigate the pest pressure and benefit seed production?

\section{Material and methods}

\section{Study system}

In total, 45 fields were included in the study that took place in the southernmost part of Sweden, Scania, in 2014-2017. 


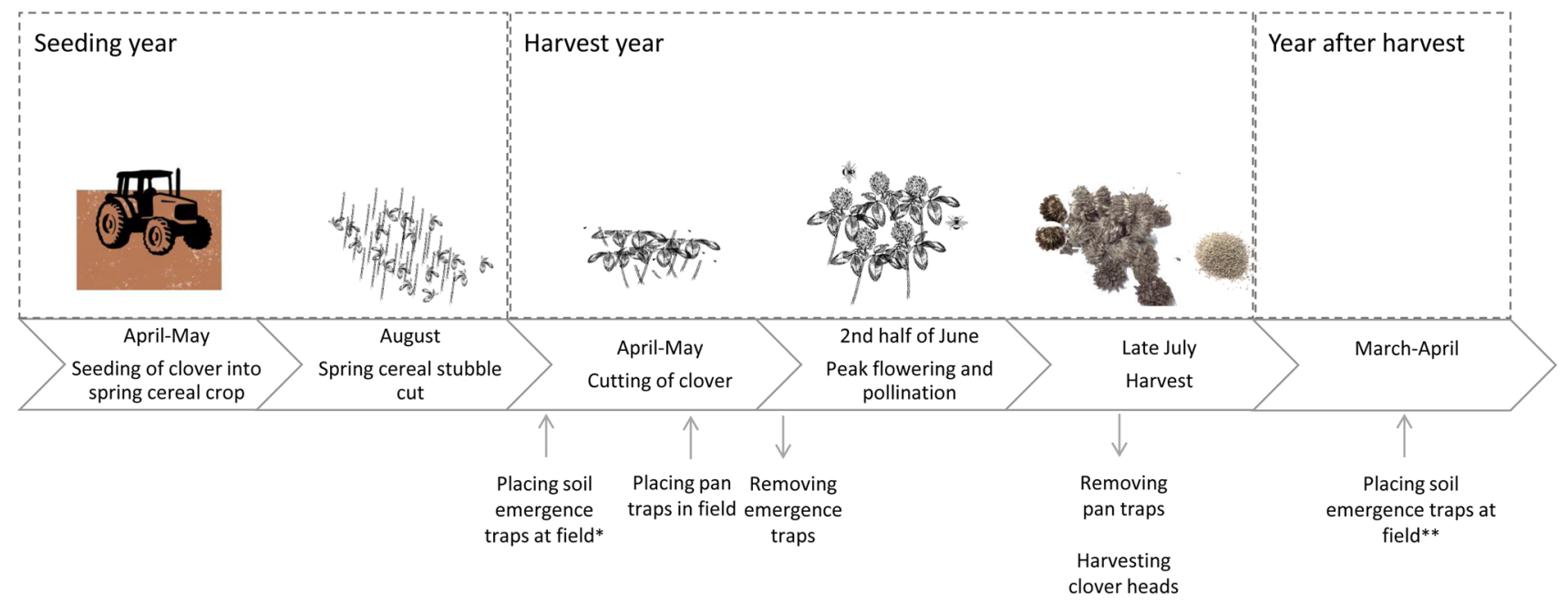

Fig. 1 Timeline for a clover seed field. In the year before harvest (seeding year) clover is sown into a cereal crop. The cereal is harvested and the stubble cut short during late summer. The clover is cut in April-May of the harvest year to even the stand, increase the number of inflorescences and to reduce weed growth. Peak flowering and pollination occur in the second half of June, and 25-30 days later, the seeds are harvested. Underneath, the timing of our experimental protocol is indicated. In the year after harvest, we placed the soil emergence traps at the same place by the field again.* $=$ the field is called the study field in the year of its harvest. $* *=$ the field is called the source field the year after its harvest

the subsequent year (study field) (i.e., to disentangle when weevils locate the new seed fields), we caught insects when emerging from overwintering. A preliminary survey was done in 2013 to test the suitability of soil emergence traps in sampling overwintering weevils and to establish the locations of overwintering sites, i.e., inside or right outside clover fields (see Supplementary Information 2 for details). We then selected five (four conventional and one organic), seven (four conv. and three org.) and seven (four conv. and three org.) of our study fields for sampling of overwintering weevils over the years 2015, 2016 and 2017, respectively (Table S1.1-S1.2). Data from 2014 were here only used as source field data to the study fields in 2015. Based on the preliminary survey, we subsequently placed soil emergence traps (BT2006 and BT2003, Bugdorm, MegaView Science Company, Taiwan, $60 \times 60 \times 60 \mathrm{~cm}$ ) outside white clover fields in early spring, April 15-21 of 2015 and 2016, and in March 25-27 of 2017 due to an unusually warm spring this year. By each study field, five sets with three emergence traps were placed at different distances from the source field (Fig. 2, exceptions in Table S1.2). i) Two sets were placed in the grassy margin right outside the study field; one on the side farthest away from the source field, and one on the side closest to the source field. ii) Two sets were placed by the source field, in the same positions as in the previous year (i.e., when the field was a study field). iii) The fifth set of traps was placed at the midpoint halfway between the study field and its source field (Fig. 2), usually in a grassy field margin, otherwise in a similar grassy area. Trap flaps were dug down and secured, so that all insects overwintering in

native field (source field) or the field to be harvested in 


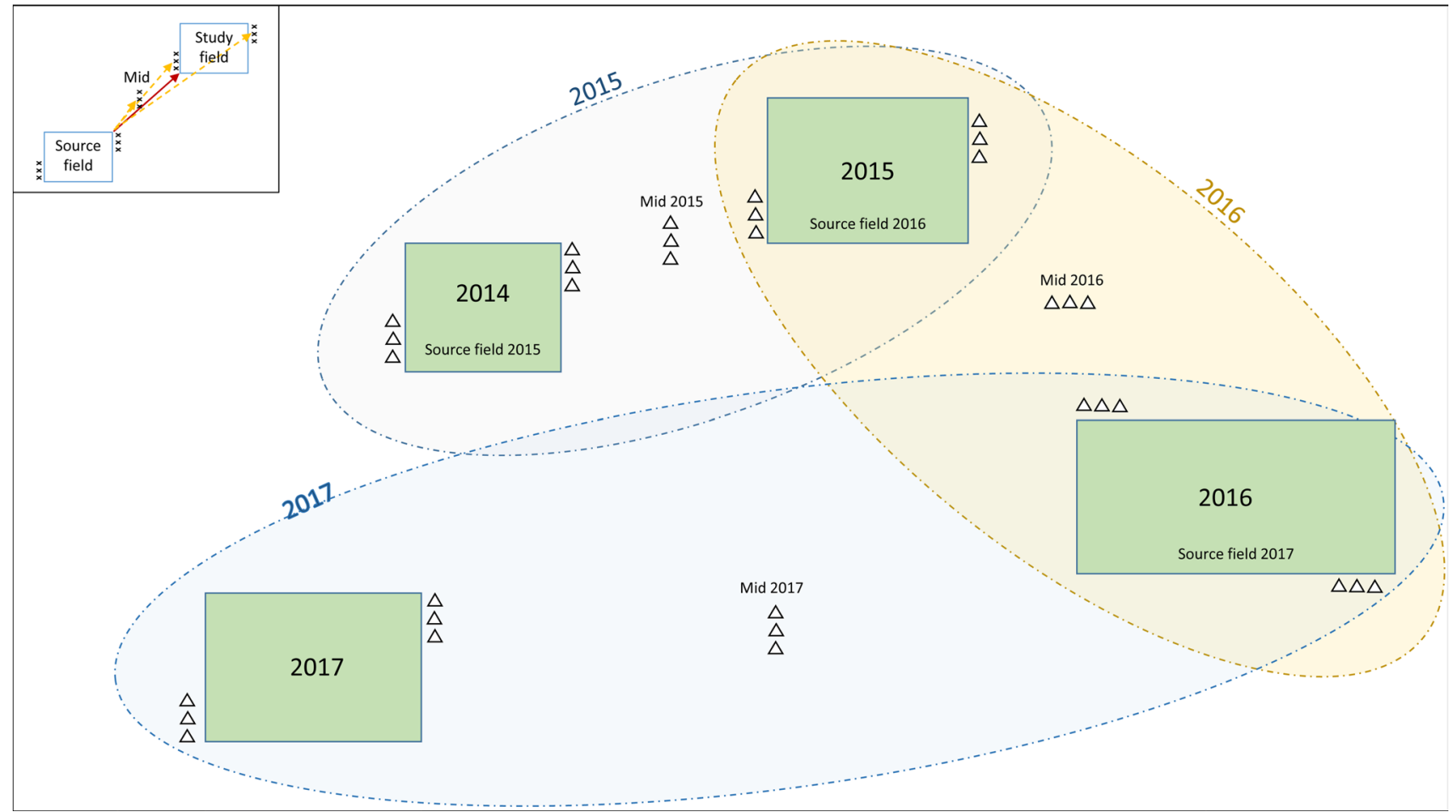

Fig. 2 Illustration of emergence trap placement at one farm during three consecutive years. Dotted lines enclose fields and traps (triangles) being part of the study per year. In the top left corner: example of emergence trap placement for one year at one farm. Distances

the covered area would crawl toward the light and end up in a 500-ml polyethylene bottle partly filled with $1 / 3$ each of water, glycol and ethanol. Bottles were emptied and refilled every third week (in total three times). Traps were removed when no more insects were emerging (June 15-17, 2015; June 20-24, 2016; June 20-22, 2017). Sampled weevils were identified to species, counted and summed per trap.

\section{Immigrating weevils}

In order to investigate the immigration of weevils into a seed field, pan traps were placed in the study fields, following methods in Lundin et al. (2017), before onset of flowering in May 2014-2017 (Table S1.3). Three pan traps were placed along the transect inside each plot in the study field, with a distance of $12.5 \mathrm{~m}$ between traps. Pan traps were fastened with tent pegs and marked with flags for ease of location. The traps were filled to approximately $3 / 4$ with water containing a drop of liquid detergent and emptied once per week for 7-8 weeks (May 23-July 16, Table S1.3). In the analyses (and from here on), we only included pan trap catches from the first five emptying rounds (May 23-June 25) because we aimed to establish immigration of weevils rather than the later reproduction and emergence of weevils from flower used in the analyses were measured from the source field to each set of emergence traps (yellow, dashed arrows), and between the closest points of the source field and the study field (red solid arrow)

heads (see motivation and details in Fig. S1.2-S1.3; Box S1.1).

\section{Incubation of flower heads for weevil emergence, assessment of flower density, seed set and pest load}

Late in crop bloom each year (July 10-21, Table S1.3), we determined the inflorescence density by counting flowering and withered flower heads in three $0.25-\mathrm{m}^{2}$ squares along each transect. At the same occasion, we collected inflorescences for incubation and emergence of clover weevils and assessment of seed set following methods described in Lundin et al. (2012, 2017). We picked 120 withered flower heads along each transect and incubated them in poster tubes with a transparent tube connected to the lid. After leaving the samples at room temperature for at least six weeks, we counted and identified the emerged weevils. To assess seed set, we counted the number of florets per flower head on 20 flower heads per transect, and the number of seeds per floret from 100 florets per transect (five florets from each of the 20 flower heads).

For analysis, the inflorescence density (from previous year's field) was used together with field size and the number of weevils emerging from flower heads to calculate the pest pressure (pest load) from the source field (pest load 
from source field $=$ mean number of flowering and withered inflorescences per $\mathrm{m}^{2} \times$ area of field in $\mathrm{m}^{2} \times$ mean number of emerged weevils per inflorescence). In conventional fields, weevils from the insecticide-treated plot (the plot treated as the rest of the field) were the basis for calculating the pest load.

\section{Statistical analyses}

Statistical analysis was performed using $\mathrm{R}$ version 4.0.4 (R Core team 2021), and results were obtained from type II Analysis of Deviance Table using Wald Chi-square tests (package car and lmerTest, function Anova, Fox and Weisberg 2011; Kuznetsova et al. 2017). Post hoc tests featuring multiple comparisons between groups were computed using estimated marginal means (function emmeans in package emmeans, Lenth 2019). The estimated marginal means show the mean response for each factor adjusted for the other variables in the model. Tests performed to answer our research questions are detailed in Table 1. Dependent variables included number of weevils in emergence traps, in pan traps and hatched from flower heads as well as number of seeds per pod. Fixed variables included combinations of management, field type and distances between fields, pest load, number of weevils, year and relevant interactions (see Table 1 for details). As random factors, we used either Farm and Field identity or Geographical area and Field identity (Table 1). For all models, we confirmed that covariates were not collinear and that model assumptions were met by checking for distribution of residuals, equal variance between groups, independence, and no overdispersion (Zuur et al. 2009, 2010). To ensure spatial independence, we included a random variable to group data collected close in space. This was either a density-dependent spatial clustering at $4 \mathrm{~km}$ (computed in ArcGIS PRO, ESRI 2020), or Farm (an area with fields belonging to one farmer), depending on what provided a better model fit (AIC and residual patterns). Results were very similar independent of this spatial grouping factor, and for analyses with fewer fields (e.g., emergence trap data), these groupings were identical. In addition, we checked for spatial autocorrelation using package DHARMa (Hartig 2021). In two cases of missing emergence trap samples among the three emptying rounds, all data from the emergence trap in question were excluded from the analysis and an offset included in the analysis. In cases of missing pan trap samples (when traps had been trampled or run over, etc., 40 out of 1035 cases), we used imputation to calculate values for the missing traps using the mean from remaining traps emptied during that round in the same transect. To get one value per transect, we then summed the number of weevils caught per trap and took the mean per transect.

Distances to source fields were determined based on landuse data from the Integrated Administration and Control
System (IACS) from the Swedish Board of Agriculture and confirmed by information from the farmers. According to this, the source field was the closest clover field in the surrounding of the study field. Distances used in the analyses were measured as i) from the source field to each set of emergence traps and ii) between the closest points of the source field and the study field (Fig. 2), using ArcGIS software 10.6 (ESRI 2017). The distance (ii) between source and study field (Table S1.1) did not differ depending on management practice (Wilcoxon: $W=729, p=0.26$ ). Neither was it correlated with the proportion area covered by clover seed fields within a radius of $1 \mathrm{~km}$ (spearman corr: $p=0.28), 3 \mathrm{~km}(p=0.51)$ and $6 \mathrm{~km}(p=0.54)$, nor to the amount of clover seed fields plus other potential clover weevil sources (leys and mixtures with clover) within $1(p=0.35), 3(p=0.69)$ and $6(p=0.60) \mathrm{km}$. We also controlled for and found no correlation between this distance measure and the proportion semi-natural land within a radius of $1 \mathrm{~km}(p=0.26), 3 \mathrm{~km}(p=0.33)$ and $6 \mathrm{~km}(p=0.28)$ from the study fields. Semi-natural land included uncultivated permanent grasslands, fallows and field border areas. The distance (i) between emergence traps and source field was, however, generally larger at conventionally managed farms (Wilcoxon: $W=8930, p=0.033$ ). Pest load was higher at organic fields, LM: $\left.\chi^{2}{ }_{1}=16.88, p<0.001\right)$. Hence, management was not included in the same analyses as distance and pest load. Every time pest load was included in a model some data were excluded, as the calculation of pest load required data from a previous year (i.e., data from the first year of a farmers set of fields could not be included in the analysis).

\section{Results}

In addition to the statistical test results presented below, summary output and analysis of deviance tables for all models are presented in Table S3.1.

\section{Weevil species composition}

Clover-associated weevils emerging from traps at overwintering sites during all years were to a large extent Protapion spp., 82\% (of which 99\% P. fulvipes), but also Sitona spp., $14 \%$, and Hypera spp., 4\%, were caught. Seventy-six percent of P. fulvipes, $83 \%$ of Hypera spp., and 67\% of Sitona spp. individuals were found at the source field, whereas $13 \%$ of the $P$. fulvipes were found at the study field and $11 \%$ at midpoints (Table 2). Pan trap catches showed a similar pattern: 92\% of trapped weevils belonged to the genus Protapion (of which $99 \%$ were P. fulvipes, Table 2), $6 \%$ to Sitona, and $2 \%$ to Hypera. Of the weevils emerging from harvested flower heads, $98.5 \%$ were Protapion spp. (of which $99.97 \%$ P. 


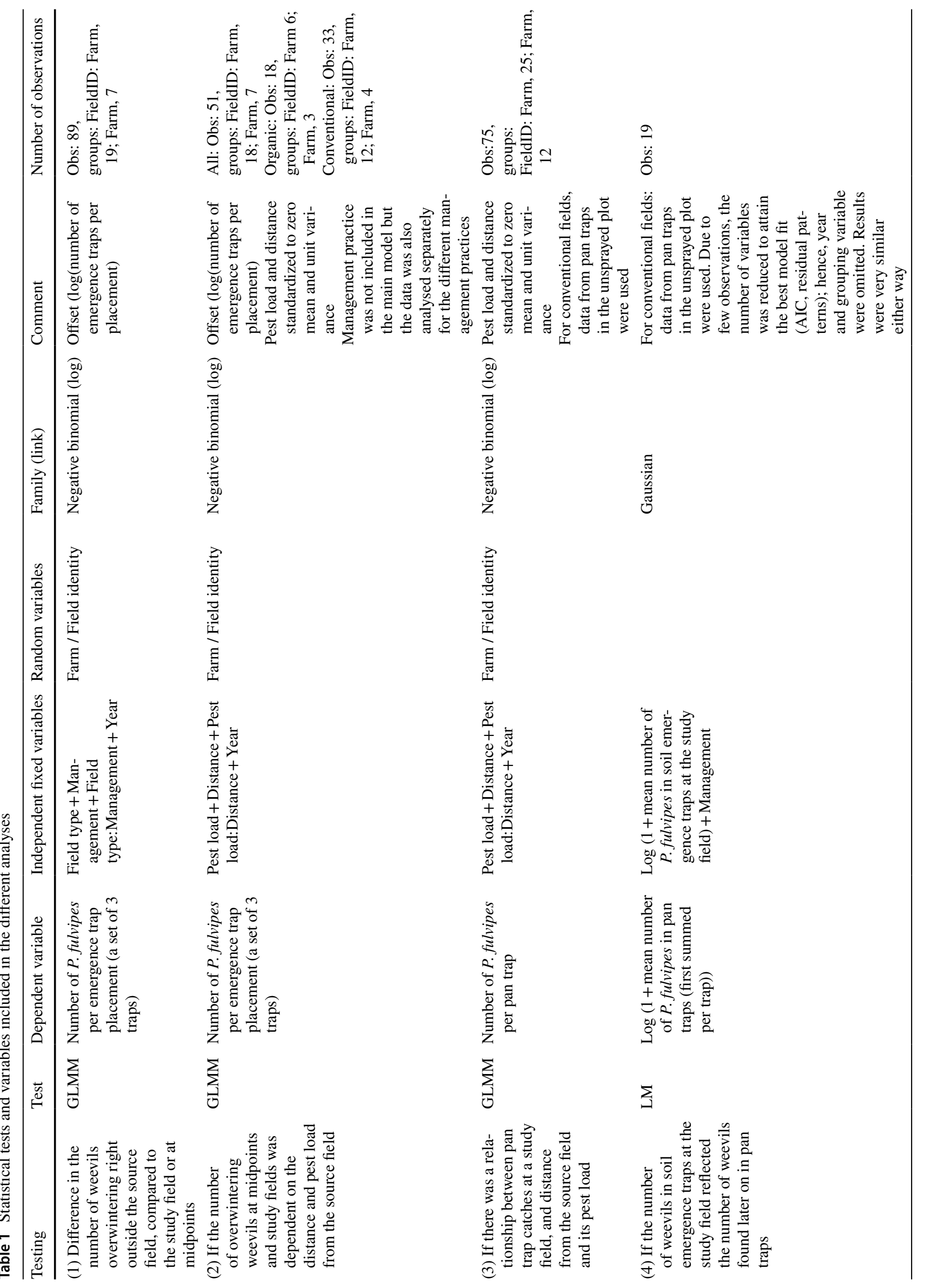




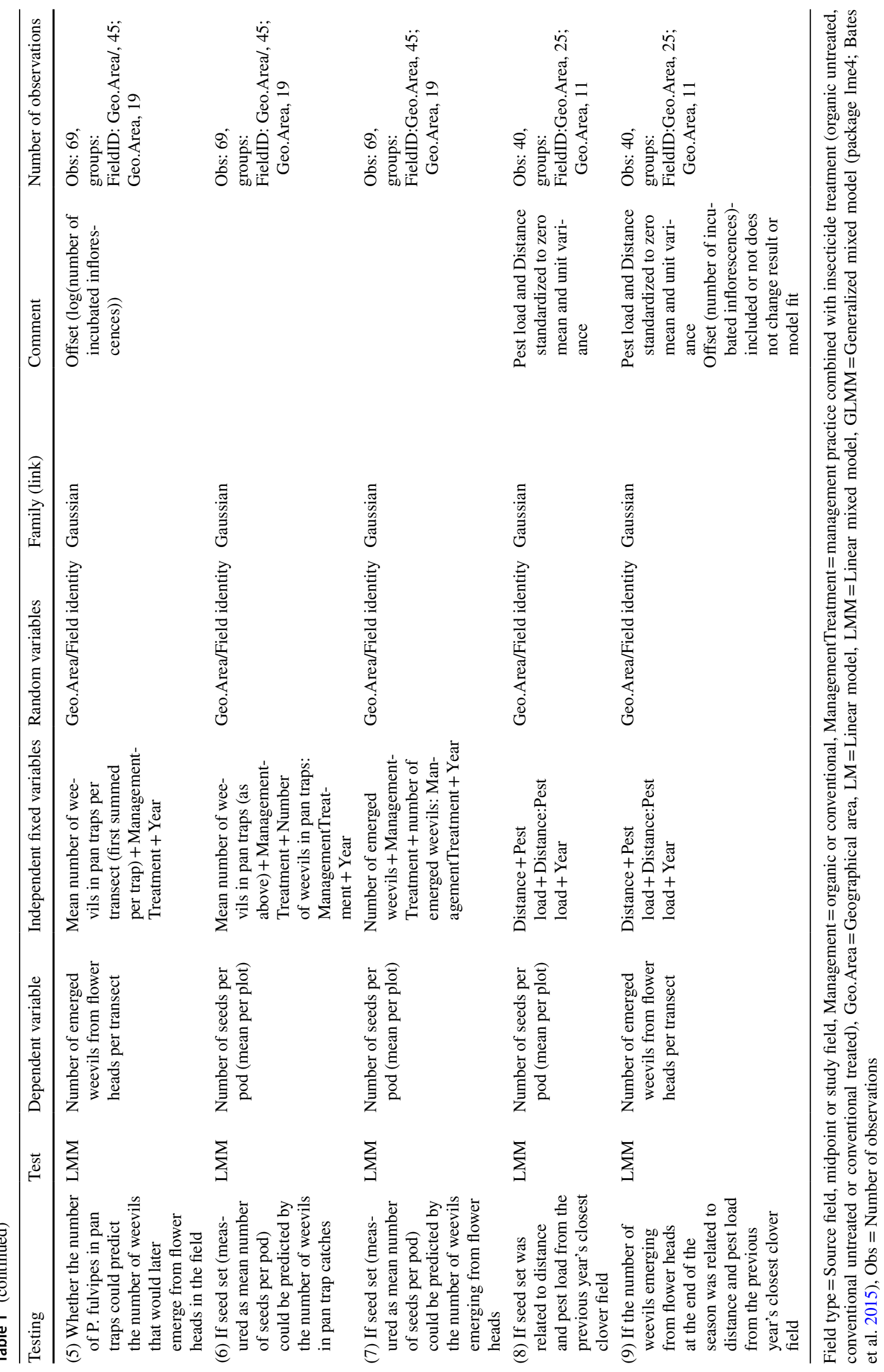


Table 2 Total number of trapped and emerged weevils

\begin{tabular}{|c|c|c|c|c|c|c|}
\hline \multirow[t]{2}{*}{ Species/group } & \multicolumn{4}{|c|}{ Weevils in emergence traps } & \multirow{2}{*}{$\begin{array}{l}\text { Weevils in pan } \\
\text { traps }\end{array}$} & \multirow{2}{*}{$\begin{array}{l}\text { Weevils emerged from } \\
\text { incubated flower heads }\end{array}$} \\
\hline & Source fields & Midpoints $^{1}$ & Study fields & Total & & \\
\hline Protapion spp. (total) & 8223 & 1209 & 1479 & 10,911 & $26,880^{2}$ & 63,600 \\
\hline P. fulvipes & 8192 & 1203 & 1416 & 10,811 & 18,004 & 63,583 \\
\hline P. apricans & 1 & 1 & 6 & 8 & 4 & 0 \\
\hline P. assimile & 0 & 0 & 0 & 0 & 5 & 0 \\
\hline P. trifolii & 5 & 1 & 6 & 12 & 30 & 17 \\
\hline$P$. virens & 25 & 4 & 51 & 80 & 179 & 0 \\
\hline Sitona spp. & 1198 & 197 & 398 & 1793 & 1885 & 8 \\
\hline Hypera spp. & 365 & 22 & 51 & 438 & 606 & 953 \\
\hline
\end{tabular}

${ }^{1}$ Note that midpoints had half the number of emergence traps compared to source and study fields

${ }^{2}$ Not sorted to species level in 2014, therefore a much higher number in Protapion spp. than in P. fulvipes here

fulvipes) and 1.5\% Hypera spp. In addition, a few individuals of $P$. trifolii and Sitona spp. were found in this material (Table 2).

\section{Weevil abundance}

\section{Overwintering weevils}

There were more weevils overwintering outside source fields than outside study fields and at midpoints $\left(\chi_{2}^{2}=27.48\right.$, $p<0.001$ ), but no difference in between midpoints and at study fields (Fig. 3). The number of weevils was also higher in emergence traps at organic fields than at conventional fields $\left(\chi_{1}^{2}=12.04, p<0.001\right.$; Fig. 3 ), although there was some variation between farms (Fig. S3.1). There was no interaction effect between trap placement and management practice $\left(\chi_{2}^{2}=1.67, p=0.43\right)$.

The number of $P$. fulvipes in emergence traps decreased with distance $\left(\chi_{1}^{2}=6.65, p=0.001\right)$ and increased with pest load from previous year's clover seed field $\left(\chi_{1}^{2} 11.39\right.$, $p<0.001$; Fig. 4a), but there was no interaction effect of distance and pest load $\left(\chi_{1}^{2}=3.23, p=0.073\right)$. When analysing the data from organic vs. conventional fields separately, the number of weevils in emergence traps at organic fields showed a similar pattern; the number of weevils decreased with distance $\left(\chi_{1}^{2}=6.77_{1}, p=0.009\right)$ and exhibited a nearsignificant increase with pest load $\left(\chi_{1}^{2}=3.55_{1}, p=0.060\right)$ from the source field and with no interaction effect between these two variables $\left(\chi_{1}^{2}=0.12, p=0.73\right)$. For data on weevils at conventional fields, we found an interaction effect between pest load and distance $\left(\chi_{1}^{2}=17.51, p<0.001\right)$, showing that when pest load was high, the number of weevils in emergence traps decreased with distance, whereas with low pest load there was no effect of distance, as the numbers were uniformly low from the source field (Fig. S3.2). We observed that one organic field had pest loads that were more extreme than the rest, and when performing the same analyses without observations from this field, we found an interaction between distance and pest load when including both conventional and organic fields $\left(\chi_{1}^{2}=9.43, p=0.002\right)$. Again, the interaction showed that when pest load was high, weevils in emergence traps decreased with distance (Fig. S3.2). When only including organic fields there was no interaction and no effect of pest load, but again the number of weevils decreased with distance (Table S3.1).

\section{Immigrating weevils and the new weevil generation}

The number of $P$. fulvipes caught in pan traps decreased with $68 \%$ (calculation in Box S3.1) per km distance from

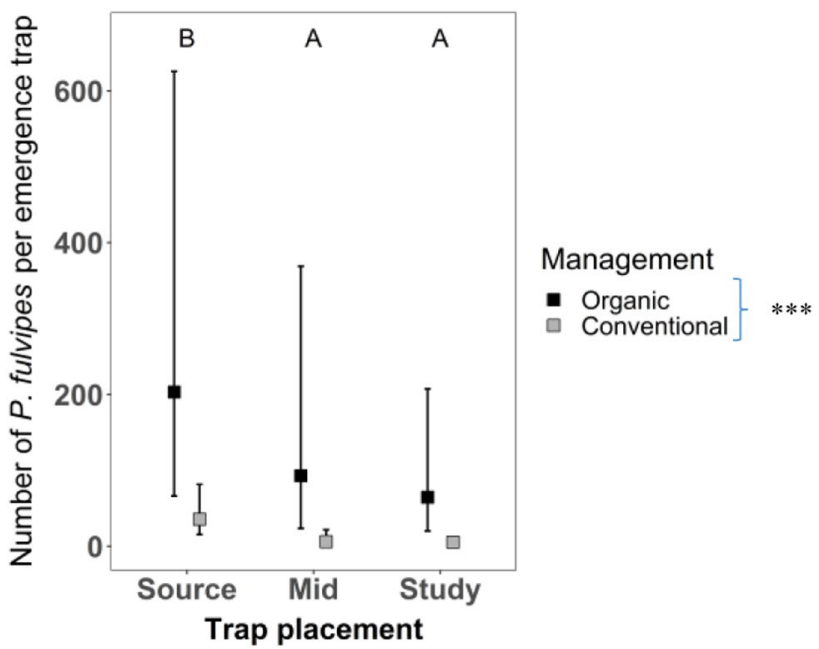

Fig. 3 Model estimated means and confidence limits (95\%) for the number of $P$. fulvipes per emergence trap in field margins of source fields, at midpoints, and at study fields in relation to management practice $($ black $=$ organic, gray $=$ conventional). Pairwise comparisons are indicated by letters, and comparison between management practices by stars. Means sharing a letter are not significantly different. $* * * p<0.001 ; * * p<0.01 ; * p<0.05 ;$ n.s., $p>0.05$ 
Fig. 4 Model predicted numbers of $P$. fulvipes in a soil emergence traps and $\mathbf{b}$ pan traps, in relation to distance from the source field

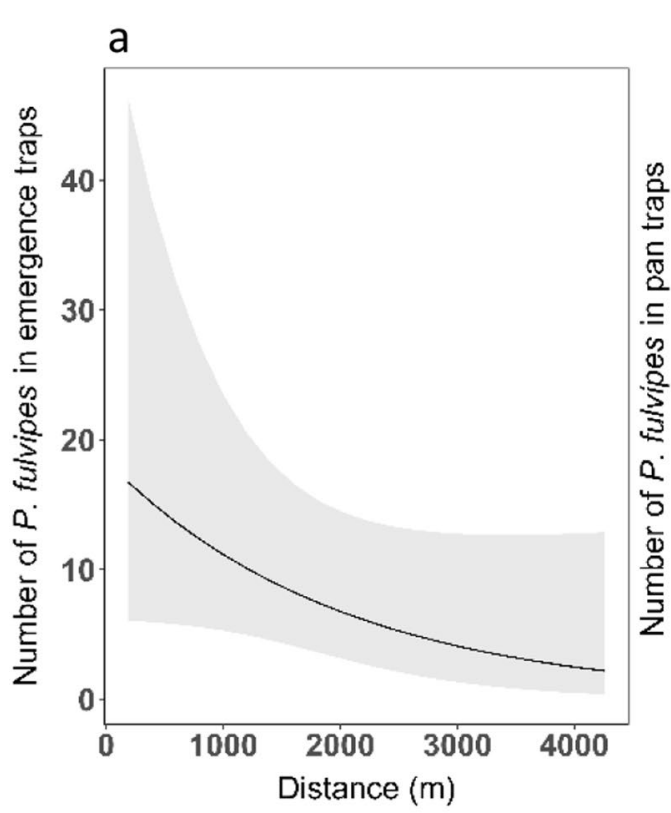

b

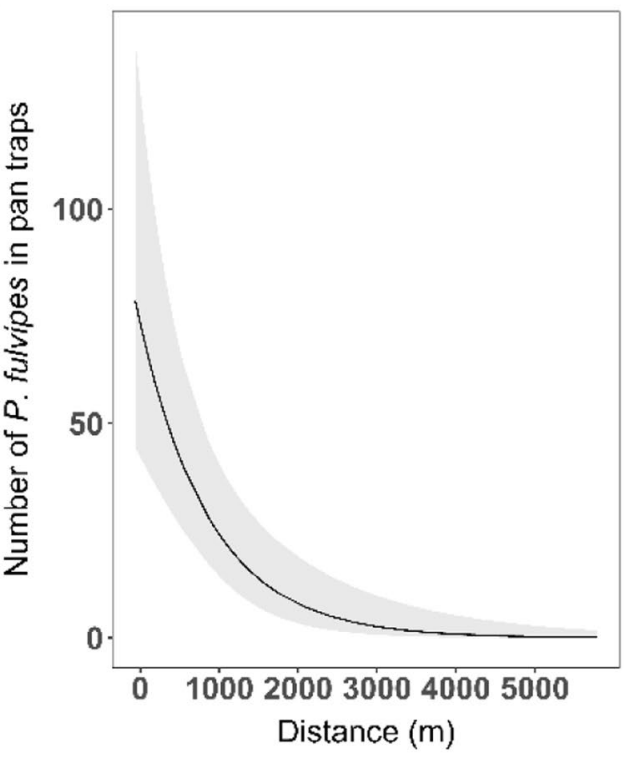

the source field (GLMM: $\chi_{1}^{2}=24.29, p<0.001$; Fig. 4b) and increased with pest load $\left(\chi_{1}^{2}=10.86, p<0.001\right)$, but there was no interaction effect of pest load and distance $\left(\chi_{1}^{2}=0.93\right.$, $p=0.34$ ). The number of weevils found in pan traps (immigrating weevils) was positively related to the number of $P$. fulvipes in soil emergence traps (overwintering weevils) earlier in the season at the same study field (LM: $F_{1}=48.64$, $p<0.001$; Fig. 5a), independent of management $\left(F_{1}=2.07\right.$, $p=0.17)$. We also found that the number of weevils emerging from flowers at the end of crop bloom (the new generation) was positively related to the number of $P$. fulvipes in pan traps (LMM: $\chi_{1}^{2}=6.49, p=0.011$; Fig. $5 b$ ). Management type and insecticide treatment also affected the number of emerging weevils ( $\left.\chi_{2}^{2}=28.95, p<0.001\right)$, and post hoc test showed that insecticide-treated conventionally managed plots had the least number of weevils, while numbers in untreated conventional and organically managed plots were not statistically different. There was no interaction effect of management and trapped weevils on the number of weevils emerging from flower heads $\left(\chi_{2}^{2}=2.35, p=0.31\right)$.

\section{Seed production and weevils}

Seeds per pod were negatively related to pan trap weevil catches (Table 3; Fig. 5c) and to the number of weevils emerging from flower heads (Table 3; Fig. 5d). Management practice and insecticide treatment also affected seeds per pod (Table 3). Post hoc tests showed that there were more seeds per pod in conventional treated plots compared to organic plots, whereas the estimated number of seeds in untreated conventional plots was in between these values (Fig. S3.3).
Because abundance of weevils in emergence traps and in pan traps was related to distance to source field and to the number of later emerging weevils from flowers, as well as to seed set, we tested whether 1) the number of weevils emerging from flower heads at the end of the season and 2) the number of seeds per pod were related to distance from the source field. Results showed that the number of weevils emerging from flower heads was negatively related to distance (Fig. 5e) and positively related to pest load from the source field (Table 3). The opposite was true for seed set, where the number of seeds per pod was positively related to distance (Fig. 5f) and negatively related to pest load from the source field (Table 3). When running the same models but excluding one observation from a field situated $6 \mathrm{~km}$ from its source field, there was an interaction between distance and pest load on the number of weevils emerging from flower heads (Table 3), with distance having a negative effect when pest load was high (Fig. S3.4), whereas the number of seeds per pod was no longer significantly positively related to distance (Table 3); however, the trend was still positive (Fig. S3.4).

\section{Discussion}

We mapped spatial and temporal population dynamics of white clover seed pests, using soil emergence traps, pan traps and incubation of inflorescences, in order to explore the potential for reducing crop yield loss through spatial planning. We found that the major seed pest, P. fulvipes and other clover-associated weevil pests primarily overwintered adjacent to the source field, i.e., the field grown with clover the 

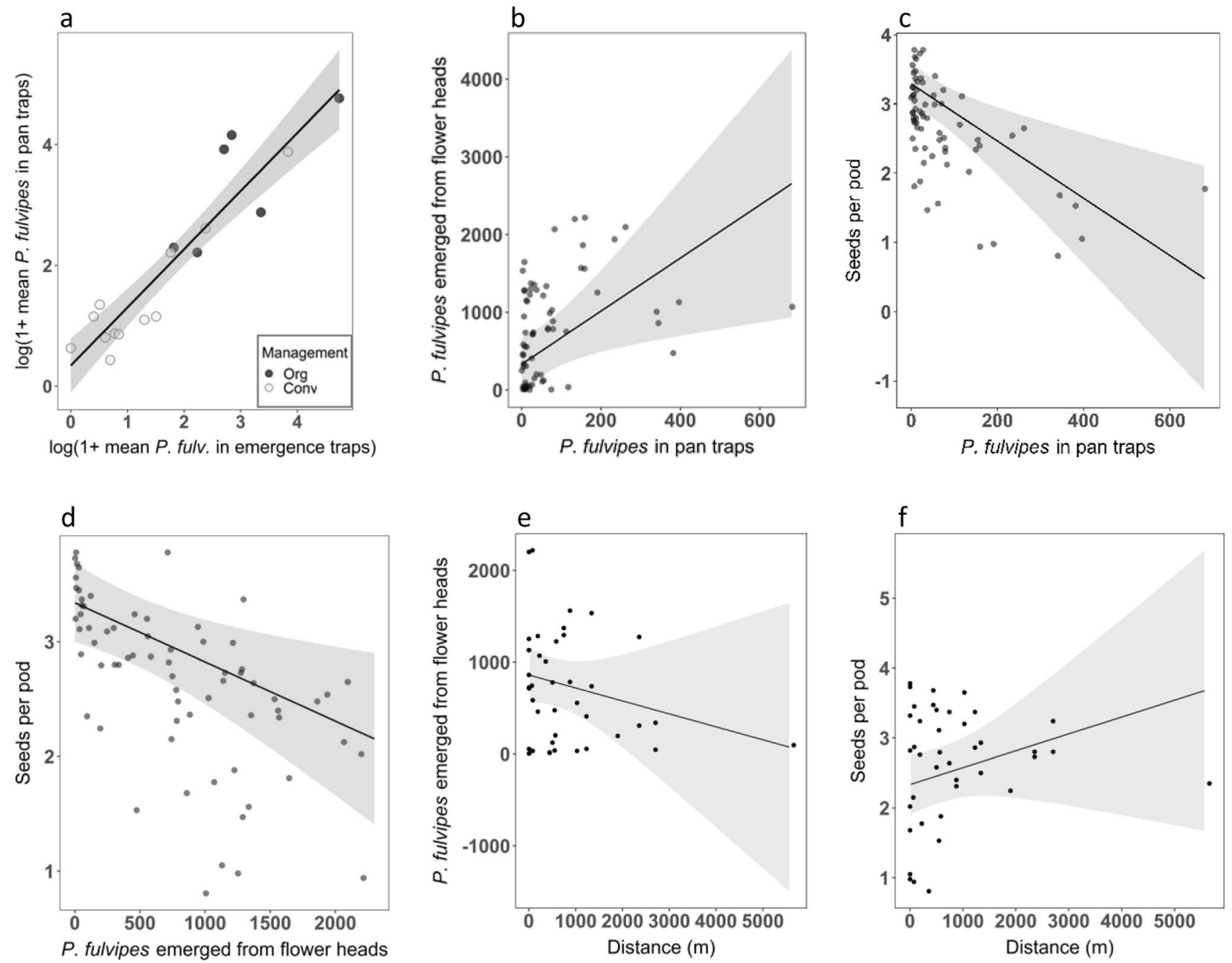

Fig. 5 a Mean number of $P$. fulvipes in emergence traps by study field related to mean number of $P$. fulvipes in pan traps later on in the same field (log-transformed with the natural logarithm). b Summed number of $P$. fulvipes in pan traps as predictor for weevils emerging from flower heads later in the season. $\mathbf{c}$ The number of $P$. fulvipes

year before the weevils emerge after winter. Pest abundance in clover seed fields to be harvested in a given year increased with pest load and decreased with distance from the previous year's clover seed field. The current estimated economic injury level for Protapion in red clover seed production is one weevil per pan trap and week (Lundin et al. 2012). To reduce the pest infestation to this level would require a distance of $2-3 \mathrm{~km}$ between white clover fields among years.

\section{Protapion fulvipes as the major seed pest in southern Sweden}

In line with Nyabuga et al. (2015), we found that $P$. fulvipes was the most abundant clover herbivore in and around white clover fields and that there were few individuals of other in pan traps, and $\mathbf{d}$ the number of emerged weevils, as predictors for seeds per pod. e The number of $P$. fulvipes that emerged from flower heads, and $\mathbf{f}$ the number of seeds per pod, in relation to distance from the source field. In a, management practice is indicated by color $($ gray $=$ organic, white $=$ conventional $)$

Protapion species present. We also found the more destructive Hypera spp. at our study sites, but congruent with Lundin et al. (2017) we found fewer Hypera spp. compared to Langer and Rohde (2005) (1.5\% vs. 7\% of weevils emerging from inflorescences). The combined results strongly suggest that $P$. fulvipes is the main pest of importance for white clover seed production in southern Sweden, with Hypera weevils constituting a considerably lesser problem in clover seed production in southern Sweden compared to in Denmark.

\section{Overwintering and mobility of $P$. fulvipes in relation to age of clover fields}

A pest's host specificity and mobility, as well as its persistence through dormant life stages, are key factors that 
Table 3 Statistical test results from analyses of seed production in relation to weevils and distance, and of weevils from inflorescences in relation to distance. ManagementTreatment $=$ management practice combined with insecticide treatment (organic untreated, conventional untreated or conventional treated). Bold values denote statistical significance at the $p<0.05$ level

\begin{tabular}{|c|c|c|c|c|c|c|c|c|}
\hline Test & Response & & $\chi^{2}$ & df & $p$ & $\chi^{2}$ & df & $p$ \\
\hline \multirow[t]{5}{*}{6} & Seeds per pod & & & & & & & \\
\hline & & Weevils in pan traps & 28.15 & 1 & $<0.001$ & & & \\
\hline & & ManagementTreatment & 21.35 & 2 & $<0.001$ & & & \\
\hline & & Year & 2.06 & 3 & 0.56 & & & \\
\hline & & Weevils...:ManagementTreatment & 2.11 & 2 & 0.34 & & & \\
\hline \multirow[t]{5}{*}{7} & Seeds per pod & & & & & & & \\
\hline & & Weevils emerged from inflorescenses & 18.43 & 1 & $<0.001$ & & & \\
\hline & & ManagementTreatment & 10.48 & 2 & $\mathbf{0 . 0 0 5 3}$ & & & \\
\hline & & Year & 7.92 & 3 & 0.048 & & & \\
\hline & & Weevils...:ManagementTreatment & 0.89 & 2 & 0.64 & & & \\
\hline \multirow[t]{5}{*}{8} & Seeds per pod & & & & & Without one value at $6 \mathrm{~km}$ & & \\
\hline & & Distance & 6.33 & 1 & 0.012 & 3.21 & 1 & 0.073 \\
\hline & & Pest load & 12.96 & 1 & $<0.001$ & 12.62 & 1 & $<0.001$ \\
\hline & & Year & 3.13 & 2 & 0.21 & 2.39 & 2 & 0.30 \\
\hline & & Distance:Pest load & 0.39 & 1 & 0.53 & 1.14 & 1 & 0.29 \\
\hline \multirow[t]{5}{*}{9} & Weevils emerged & & & & & Without one value at $6 \mathrm{~km}$ & & \\
\hline & from inflores- & Distance & 10.07 & 1 & 0.0015 & 3.96 & 1 & 0.047 \\
\hline & & Pest load & 12.29 & 1 & $<0.001$ & 14.23 & 1 & $<0.001$ \\
\hline & & Year & 1.90 & 2 & 0.39 & 3.14 & 2 & 0.21 \\
\hline & & Distance:Pest load & 3.02 & 1 & 0.082 & 4.17 & 1 & 0.041 \\
\hline
\end{tabular}

determine whether crop rotation, i.e., movement of a crop in time and space, is an efficient pest management strategy (Mohler and Johnson 2009). Although P. fulvipes is specific in its host range (Markkula and Myllymaki 1957, 1964; Gønget 1997), there is little information as to where this pest overwinters, when it locates the new clover seed field, and how mobile it is. According to Gønget (1997), P. fulvipes is an active flyer, more so than relatives such as $P$. apricans, $P$. assimile and P. trifolii (Bovien and Jørgensen 1936).

The premise for this four-year study involving 45 white clover fields was based on the assumption that last year's clover field constituted the main source of clover weevils in the agricultural landscape under study. Similar to Ohlsson (1968), we observed that $P$. fulvipes remained close to the field from where they emerged when overwintering. The weevils overwintered to a higher extent adjacent to the source fields compared to margins of study fields or in the landscape between fields. Furthermore, there was no difference in weevil abundance in emergence traps placed halfway between fields compared to emergence traps close to the study fields, which could have potentially acted as attractors for dispersing weevils looking for overwintering sites. This, together with our observation that the number of weevils was low in the study field early on in the harvest year, indicates that the weevils do not disperse in large numbers to the study field in the autumn of the previous year. We found more overwintering weevils at organic fields compared to conventional fields, but the difference between source and study field was not influenced by management practice.

\section{Influence of pest load and distance on $P$. fulvipes abundance and white clover seed loss}

We show that both distance to, and magnitude of the pest load of the source field affect the number of $P$. fulvipes close to and inside the study field. The number of weevils fall below the estimated economic injury level of one weevil per pan trap and week (Lundin et al. 2012) at 2-3 km distance from the previous year's clover seed field. Our results, demonstrating that weevil abundance in the landscape is closely related to the presence of individual white clover seed fields, provide strong evidence that the seed fields constitute the main sources of white clover weevils in the agricultural landscape context. Similarly, abundance of the red clover pest $P$. trifolii tended to be higher in the presence of a red clover field within $800 \mathrm{~m}$ from the previous year's field (Lundin et al. 2016), and higher numbers of $P$. fulvipes in white clover fields were previously found in the presence of a source field within $1 \mathrm{~km}$ (Langer and Rohde 2005). 
Because $P$. fulvipes and its host plants are widespread both in the wild and in leys in the agricultural landscape, the presence of various sources of white clover could have influenced our results. Langer and Rohde (2005) suggested that substantial amounts of feral clover in their Danish study area would support background levels of clover seed weevils high enough to preclude relocation of seed fields as a viable strategy to prevent economically relevant crop damage. However, the area where our study was conducted was consistent with the presumptions: the proportion of wild and feral clover was low, and through the IACS database we had information regarding the positions of all clover fields or leys in the area. Congruently, we found no correlation between the amount of clover fields or semi-natural areas in the landscape and our distance measures. Moreover, leys are generally not allowed to mature long enough before harvest to constitute a significant source of seed weevils; thus, any potential leys not reported in the IACS system were presumably not important.

Furthermore, we found that the number of weevils immigrating into the field early in the season positively correlated with the number of weevils that later emerged from inflorescences, and that these in turn were negatively related to the number of seeds per pod at harvest. This is in line with results by Lundin et al. (2017). We found most seeds per pod in conventionally treated plots, whereas the greatest loss to seed-eating weevils occurred in organic fields. We also showed that seeds per pod could be predicted directly by pan trap catches and that seed set increased with distance to, and decreased with pest load of, the previous year's field. In contrast, the number of weevils emerging from flower heads decreased with distance and increased with pest load. It should be noted that most of our observations were within $3 \mathrm{~km}$ of the source field. Excluding the only observation with a longer distance to the source field $(6 \mathrm{~km})$, i.e., testing the relationship for shorter distances only, showed that number of weevils emerging from the flowers was decreasing more with distance when pest load was high than when it was low. For shorter distances, the influence on seed set was not significant (but the trend was still the same). In order to directly predict the effect of distance on seed set, we would need more observations at different distances from the source field. In any case, our results confirm that $P$. fulvipes causes significant damage to clover seeds (Langer and Rohde 2005; Lundin et al. 2017) and affirm that preventing weevils from finding the new seed field in the first place is of great importance.

\section{Spatial planning as a control measure of $P$. fulvipes}

Using mark-recapture experiments, Follet et al. (1996) suggested that an effective crop rotation to reduce Colorado potato beetle population densities from year to year would require a distance of $\geq 500 \mathrm{~m}$ from previous year's potato field. Our study demonstrates that the distances between white clover seed fields in consecutive years constitute an important factor in limiting the pressure of seed-eating Protapion weevils, and spatial planning could therefore provide a means to increase yields in general, and especially for organic growers. Increasing distances between white clover seed fields in consecutive years appears to provide continuously increasing benefits at least up to a distance of a few kilometers. We therefore recommend a general implementation of spatial planning to keep seed production fields with a large enough distance between fields in different years, in order to spatially escape pest weevils and prevent population build-up. If the areas of individual farms are too small to allow for sufficient separation between years, overcoming this would require grower cooperation. To cope with problems with pollen beetles in oil seed rape, researchers have suggested crop rotation management at the landscape scale, an intervention occurring at scales greater than farm units (Skellern and Cook 2018a, b).

In our recommendations, we have not considered the potential effects of spatial separation of clover fields on natural enemies and other factors that may alleviate pest pressure. Natural enemies are especially important in organic farming, as insecticide use in conventional farming keeps pests under control. Bianchi et al. (2006) concluded that diversified landscapes hold most potential for conservation of biodiversity and thereby sustaining pest control function (i.e., control by natural enemies). Natural enemies of several Protapion species, including P. fulvipes, have been shown (in red clover) to be more sensitive to lack of connectivity between habitats than their hosts (Kruess and Tscharntke 1994). Current knowledge regarding maximizing ecosystem services in pollination and pest control would suggest keeping smaller seed production fields, to reduce the pest population buildup, contributing to a more diversified landscape, and reducing the distance to areas harboring pest natural enemies. However, if the same area for seed production is required, dividing the total area into greater numbers of smaller fields could mean smaller distance between fields, which would facilitate pest dispersal between seasons. The practice with smaller fields and maintained sown area would therefore only work positively for seed yield if the natural enemies of $P$. fulvipes are efficient at controlling the pest. The effect of natural enemies on $P$. fulvipes in white clover seed production, with different spatial allocation patterns of seed fields, needs to be further investigated.

\section{Summary and conclusion}

In this four-year study on 45 white clover fields, pest weevils overwintered to a higher extent adjacent to the source field (the previous year's seed field), compared to adjacent to the 
study field (the current year's seed field). As the season progressed, there was increased immigration of $P$. fulvipes into the study fields. A higher pest load, i.e., the total number of weevils hatched, of the source field in one year resulted in an increase of weevils in nearby study fields in the following year. Higher pan trap catches, i.e., higher numbers of immigrating weevils, in turn resulted in higher pest loads in the mature flower heads and severely reduced numbers of seeds per pod during harvest. This effect was greatly mitigated by insecticide treatments in conventional fields, but also by increased distances between fields in subsequent years. An increased distance from the source field resulted in a decreased number of overwintering weevils near the study field, as well as a reduced number of weevils caught in pan traps or emerging from inflorescences inside the study field later in the season. This points to spatial management as a promising IPM tool to mitigate local population build-up of pests; particularly within organic farming, where insecticide use is not an option, but also as an alternative to insecticide use in conventional farming. We suggest that reducing the size of and separating seed production fields with $2-3 \mathrm{~km}$, and/or only growing white clover for seed every other year, would result in both spatial and temporal escapes from the seed-predating weevil pest. However, it should be kept in mind that alternate growing over years or greatly increasing distances between clover fields beyond $2-3 \mathrm{~km}$ between years could be a disadvantage for pollinators and pollination of the crop (Rundlöf et al. 2014; Lundin et al. 2017).

Supplementary Information The online version contains supplementary material available at https://doi.org/10.1007/s10340-021-01408-w.

Acknowledgements We thank all white clover seed farmers and landowners for allowing us to work on their land. We also thank Delphine Lariviere, Maria Blasi Romero, Johanna Yourstone, Anna Douhan Sundahl and Laura Guia Diaz for fieldwork and laboratory assistance. We also thank Katarina Hedlund and Helena Hansson, who lent us a large number of emergence traps, and Adam Flöhr who provided valuable statistical consultation.

Author Contribution MCL, ÅL, MR, GPS and OA secured funding. All authors conceptualized and designed the study. VH and FNN collected the data. VH analysed the data. The manuscript was drafted by $\mathrm{VH}$ and edited by all authors.

Funding Open access funding provided by Swedish University of Agricultural Sciences. This study was financed by grants from the Swedish Research Council for Environment, Agricultural Sciences and Spatial Planning (FORMAS), Swedish Farmers' Foundation for Agricultural Research (SLF) and by Partnerskap Alnarp in collaboration with Swedish Seed and Oilseed Growers' Association.

\section{Declarations}

Conflict of interest The authors declare that they have no conflict of interest.
Open Access This article is licensed under a Creative Commons Attribution 4.0 International License, which permits use, sharing, adaptation, distribution and reproduction in any medium or format, as long as you give appropriate credit to the original author(s) and the source, provide a link to the Creative Commons licence, and indicate if changes were made. The images or other third party material in this article are included in the article's Creative Commons licence, unless indicated otherwise in a credit line to the material. If material is not included in the article's Creative Commons licence and your intended use is not permitted by statutory regulation or exceeds the permitted use, you will need to obtain permission directly from the copyright holder. To view a copy of this licence, visit http://creativecommons.org/licenses/by/4.0/.

\section{References}

Baker MJ, Williams WM (1987) White clover. CAB International, Wallingford

Bates D, Maechler M, Bolker B, Walker S (2015) Fitting linear mixedeffects models using lme4. J Stat Softw 67:1-48

Bianchi FJJA, Booij CJH, Tscharntke T (2006) Sustainable pest regulation in agricultural landscapes: a review on landscape composition, biodiversity and natural pest control. Proc Royal Soc B 273:1715-1727

Bovien P, Jørgensen M (1934) Orienterende undersøgelser over angreb af snudebiller (Apion) i kløverhoveder. (Preliminary investigations on attacks of Apion in clover heads). Tidskrift För Planteavl 40:376-398

Bovien P, Jorgensen M (1936) Fortsatte unders $\varnothing$ gelser over angreb af snudebiller (Apion) i kløverhoveder (Further investigations of attacks of Apion spp. in clover heads). Tidskrift for Planteavl 41:337-353

Bullock DG (1992) Crop-rotation. CRC Crit Rev. Plant Sci 11:309-326

Chapman JW, Reynolds DR, Wilson K (2015) Long-range seasonal migration in insects: mechanisms, evolutionary drivers and ecological consequences. Ecol Lett 18:287-302

Dent D (2000) Insect pest management. CABI Publishing, Wallingford

Dingle H (2014) Migration: the biology of life on the move, 2nd edn. Oxford University Press, Oxford

Dingle H, Drake VA (2007) What is migration? Bioscience 57:113-121

ESRI (2017) ArcGIS Desktop: Release 10.6 Redlands, CA: Environmental Systems Research Institute

ESRI (2020) ArcGIS Pro 2.7.0 Redlands, CA: Environmental Systems Research Institute

Follet PA, Cantelo WW, Roderick GK (1996) Local dispersal of overwintered Colorado potato beetle (Chrysomelidae: Coleoptera) determined by mark and recapture. Environ Entomol 25:1304-1311

Fox J, Weisberg S (2011) An $\{\mathrm{R}\}$ Companion to Applied Regression, Second Edition. CA: Sage publications, Thousand Oaks. http:// socserv.socsci.mcmaster.ca/jfox/Books/Companion

Freeman BE (1965) An investigation of the distribution during winter of the white clover seed weevil, Apion dichroum Bedel (Col. Curculionidae). J Appl Ecol 2:105-113

Freeman BE (1967) Biology of white clover seed weevil Apion dichroum Bedel (Col. Curculionidae). J Appl Ecol 4:535-552

Gønget H (1997) Fauna Entomologica Scandinavica; The Brentidae (Coleoptera) of Northern Europe, vol 34. Brill Academic Publishers, Leiden

Hansen LM, Boelt B (2008) Thresholds of economic damage by clover seed weevil (Apion fulvipes Geoff.) and lesser clover leaf weevil (Hypera nigrirostris Fab.) on white clover (Trifolium repens $\mathrm{L}$.) seed crops. Grass Forage Sci 63:433-437 
Hartig F (2021) DHARMa: Residual Diagnostics for Hierarchical (Multi-Level / Mixed) Regression Models. R package version 0.4.0. https://CRAN.R-project.org/package=DHARMa

Jones JM (1950) Clover seed weevils. Ann Appl Biol 37:313-320

Kim KS, Sappington TW (2013) Population genetics strategies to characterize long-distance dispersal of insects. J Asia Pac Entomol 16:87-97

Kogan M (1998) Integrated pest management: historical perspectives and contemporary developments. Annu Rev Entomol 43:243-270

Kruess A, Tscharntke T (1994) Habitat fragmentation, species loss and biological control. Science 264:1581-1584

Kuznetsova A, Brockhoff PB, Christensen RHB (2017) lmerTest package: tests in linear mixed effects models. J Stat Softw 82:1-26

Langer V, Rohde B (2005) Factors reducing yield of organic white clover seed production in Denmark. Grass Forage Sci 60:168-174

Lenth R (2019) emmeans: Estimated Marginal Means, aka LeastSquares Means. R package version 1.3.2. https://CRAN.R-proje ct.org/package $=$ emmeans. Accessed 2 Feb 2019

Lundin O, Rundlöf M, Smith HG, Bommarco R (2012) Towards integrated pest management in red clover seed production. J Econ Entomol 105:1620-1628

Lundin O, Rundlöf M, Smith HG, Bommarco R (2016) Historical change and drivers of insect pest abundances in red clover seed production. Agric Ecosyst Environ 233:318-324

Lundin O, Svensson GP, Larsson MC, Birgersson G, Hederström V, Lankinen $\AA$, Anderbrant O, Rundlöf M (2017) The role of pollinators, pests and different yield components for organic and conventional white clover seed yields. Field Crops Res 210:1-8

Markkula M, Myllymaki S (1957) Investigations into the oviposition on red and alsike clover and alfalfa of Apion apricans Herbst, $A$. assimile Kirby, A. flavipes Payk., A. seniculus Kirby and A. virens Herbst (Col., Curculionidae). Annales Entomologicae Fennicae 23:203-207

Markkula M, Myllymaki S (1964) The abundance of seed pests of alsike and white clover in Finland. Annales Agriculturae Fennicae 3:235-243

Mohler CL, Johnson SE (2009) Crop Rotation on Organic Farms: A Planning Manual. Natural Resource, Agriculture, and Engineering Service, Ithaca, NY

Nyabuga FN, Carrasco D, Ranåker L, Andersson MN, Birgersson G, Larsson MC, Lundin O, Rundlöf M, Svensson GP, Anderbrant O, Lankinen $\AA$ (2015) Field abundance patterns and odor-mediated host choice by clover seed weevils, Apion fulvipes and Apion trifolii (Coleoptera: Apionidae). J Econ Entomol 108:492-503

Oerke EC (2006) Crop losses to pests. J Agric Sci 144:31-43

Oerke EC, Dehne HW, Schönbeck F, Weber A (1994) Crop production and crop protection: estimated losses in major food and cash crops. Elsevier, Amsterdam

Ohlsson B (1968) Studies of Apion species on clover in Sweden (Col., Curculionidae). 1. Short range dispersal and choice of hibernation sites of species injurious to cultivated clover. National Swedish
Institute for Plant Protection, Contributions, 14:97-121. Stockholm, Sweden

Pimentel D, McLaughlin L, Zepp A, Lakitan B, Kraus T, Kleinman P, Vancini F, Roach WJ, Graap E, Keeton WS, Selig G (1991) Environmental and economic impacts of reducing U.S. agricultural pesticide use. In: Pimentel D (ed) Handbook on pest management in agriculture. CRC Press, Boca Raton, pp 679-718

R Core Team (2021) R: a language and environment for statistical computing. R Foundation for Statistical Computing, Vienna, Austria. https://www.R-project.org/.Rebek EJ, Frank SD, Royer TA, Bográn CE (2012) Alternatives to chemical control of insect pests In: Soloneski S, Larramendy M (eds.), Insecticides-basic and other applications. InTech, Rijeka, pp 171-196

Rebek EJ, Frank SD, Royer TA, Bográn CE (2012) Alternatives to chemical control of insect pests In: Soloneski S, Larramendy M (eds) Insecticides—basic and other applications. InTech, Rijeka, pp 171-196

Rundlöf M, Persson AS, Smith HG, Bommarco R (2014) Late-season mass-flowering red clover increases bumble bee queen and male densities. Biol Conserv 172:138-145

Skellern MP, Cook SM (2018a) The potential of crop management practices to reduce pollen beetle damage in oilseed rape. Arthropod-Plant Interact 12:867-879

Skellern MP, Cook SM (2018b) Prospects for improved off-crop habitat management for pollen beetle control in oilseed rape. ArthropodPlant Interact 12:849-866

Stockdale EA, Lampkin NH, Hovi M, Keatinge R, Lennartsson EKM, Macdonald DW, Padel S, Tattersall FH, Wolfe MS, Watson CA (2001) Agronomic and environmental implications of organic farming systems. Adv Agron 70:261-327

Svensk raps (2018) Vitklöver - odlingsvägeldning. https://www.svens kraps.se/kunskap/pdf/00140_vitklover.pdf. Accessed 28 Nov 2018

Swedish Board of Agriculture (2019) Vitklöver- odlingsråd vid ekologisk fröodling. https://www2.jordbruksverket.se/download/ 18.2b8ca76b170f13261f77497d/1584712162624/ovr546.pdf Accessed 14 Apr 2021

Wolfenbarger D (1946) Dispersion of small organisms. Distance dispersion rates of bacteria, spores, seeds, pollen, and insects; Incidence rates of diseases and injuries. Am Midl Nat 35:1-152

Zalucki MP, Adamson D, Furlong MJ (2009) The future of IPM: whither or wither? Aust J Entomol 48:85-96

Zuur A, Ieno EN, Walker N, Saveliev AA, Smith GM (2009) Mixed effects models and extensions in ecology with R. Springer, New York

Zuur AF, Ieno EN, Elphick CS (2010) A protocol for data exploration to avoid common statistical problems. Methods Ecol Evol 1:3-14

Publisher's Note Springer Nature remains neutral with regard to jurisdictional claims in published maps and institutional affiliations. 